\title{
(Re)production of symbolic boundaries between native and non-native teachers in the TESOL profession
}

\author{
Natalia Wright ${ }^{1,2^{*}}$
}

*Correspondence:

2466986w@student.gla.ac.uk

1 University of Glasgow,

Glasgow, UK

Full list of author information

is available at the end of the

article

\begin{abstract}
Although various attempts to confront non-native teachers of English (NNESTs) marginalisation in the language teaching profession have taken place over the past few years, the English language teaching (ELT) domain clearly demonstrates quite the opposite; remaining structured and articulated by boundaries that are shaped by language ideologies, it marks an exclusion of non-native English teachers from participating in the field of foreign language teaching on equal terms with native English-speaking teachers (NESTs). Using a Bourdieusian lens (Bourdieu and Passeron in Reproduction in education, society and culture, Sage, London, 1990; Bourdieu in Language and symbolic power, Harvard University Press, Cambridge, 1991), this paper examines the way symbolic violence is exercised through exclusionary and discriminatory practices that arbitrarily impose the culture of a dominant group and result in the production and reproduction of symbolic boundaries between native and non-native teachers of English. In doing so, it calls for greater awareness among language educators of the power dynamics behind the simplistic 'native'/'non-native' dichotomies. Since nothing has been done so far to reconcile the two, the author believes that a continuous perception of NESTs and NNESTs as two different professional classes might serve the interest of those who wish to maintain such polarisation.
\end{abstract}

Keywords: Native English-speaking teacher, Non-native English-speaking teacher, Bourdieu, Capital, Symbolic violence, Inequality

\section{Introduction}

Seldom in the annals of an academic discipline have so many people toiled so hard, for so long, and achieved so little in their avowed attempt at disrupting the insidious structure of inequality in their chosen profession. (Kumaravadivelu, 2016, p. 82)

Anyone who enters the profession of Teaching English to Speakers of Other Languages (TESOL) sooner or later realises that their position in the field is influenced by the amount of the resources or 'capital' (Bourdieu, 1986) they possess. English Language Teaching (ELT), permeated by the ideology of 'native speakerism' (Holliday, 2005), makes the field a terrain for struggle and contestation in which teachers compete for

(c) The Author(s) 2022. Open Access This article is licensed under a Creative Commons Attribution 4.0 International License, which permits use, sharing, adaptation, distribution and reproduction in any medium or format, as long as you give appropriate credit to the original author(s) and the source, provide a link to the Creative Commons licence, and indicate if changes were made. The images or other third party material in this article are included in the article's Creative Commons licence, unless indicated otherwise in a credit line to the material. If material is not included in the article's Creative Commons licence and your intended use is not permitted by statutory regulation or exceeds the permitted use, you will need to obtain permission directly from the copyright holder. To view a copy of this licence, visit http:// creativecommons.org/licenses/by/4.0/. 
their professional legitimacy. In these settings, the privileged status of a native English speaker (NS) guarantees native English-speaking teachers (NESTs) unmistakable recognition as ideal language educators, often regardless of their academic credentials. In contrast, qualified non-native English-speaking teachers (NNESTs) often struggle to prove their worthiness.

Despite numerous efforts to confront NNEST marginalisation over the past few years (TESOL, 1992, 2006), not only does inequity in the field continue to flourish; it has become more prominent in the era of globalisation strongly attached to its neoliberal principles that have authorised native speakerism as legitimate discourse. Noteworthy is also the fact that, against the commonly-held assumption that globalisation has created a 'borderless world' allowing people to move in response to better job prospects, the current situation in the Teaching English as a Foreign Language (TEFL) employment area clearly demonstrates quite the opposite. Remaining structured and articulated by language ideologies, it inevitably excludes NNESTs from the job market. Moreover, such treatment of NESTs and NNESTs as 'two different species' (Medgyes, 1994, p. 25) reflects socioculturally-constituted distinctions reified as symbolic boundaries or 'the lines that include and define some people, groups, and things while excluding others' (Epstein, 1992, p. 232).

Using Bourdieu's theorisation of capital and symbolic violence (Bourdieu, 1986, 1991; Bourdieu \& Passeron, 1990), my paper intends to examine the ways this force manifests itself in the perpetuation of the dominant ideology of native speakerism in such a way that NNESTs are positioned far behind the arbitrarily drawn symbolic boundaries constructed through exclusionary and discriminatory ELT practices.

In doing so, I hope to expose the hidden ideological mechanisms that underlie the NSNNS division and reveal their main causes and consequences. Next, I seek to interpret the tensions around the dichotomised notions of 'native' and 'non-native' by blurring the previously clear border between the two groups. Then, I attempt to answer why the NEST-NNEST categorisation still persists and in whose interests. Finally, I draw attention to the importance for all language professionals to resist the hegemony of a native speaker and overcome potentially harmful polarisation through their own actions.

The topic is also explored in relation to my personal experience of being and becoming a non-native English-speaking educator. This way, it provides an avenue for the author and the reader to connect theory with the real world. Although my central focus was inequity in the employment domain, I could not avoid touching upon a number of other concerns, as this theme plugs into a wider range of issues to which native speakerism is unequivocally related.

\section{Inequality between NESTs and NNESTs: defining the problem}

Much of the discussion around the issue of inequality between NESTs and NNESTs has been initiated in the past three decades in response to the unequal treatment of nonnative English-speaking teachers in various ELT contexts (Cook, 1999; Davies, 1991, 2003; Derivry-Plard, 2016; Liu, 1999; Llurda, 2006; Mahboob, 2005, 2010; Medyges,1994; Moussu \& Llurda, 2008; Paikeday, 1985; Rampton, 1990). These conversations are typically handled along the lines of polarising labels of native versus non-native teachers, where NESTs are often depicted as superior, privileged, and legitimate teachers of 
English. At the same time, NNESTs are viewed as a deficient 'professional underclass' (Rivers, 2018, p. 190) whose validity and worth are constantly being questioned by all stakeholders, themselves included.

Such 'unprofessional favouritism' (Medgyes, 2001, p. 433) of NESTs and the marginalisation of the NNESTs prevalent in many of the ELT settings is particularly evident in discriminatory recruitment biases conformed to the principles of selectiveness based on teacher's origin, accent, credibility, and appearance (Braine, 1999b, 2010; Clark \& Paran, 2007; Mahboob \& Golden, 2013; Moussu, 2006; Ruecker \& Ives, 2015; Selvi, 2010, 2014). For example, Mahboob and Golden (2013), among others, describe discriminatory practices related to the employment of NNESTs in job advertisements in the Middle East as a 'worrisome trend' (p. 78). Their study included an evaluation of 77 online job advertisements, of which 61 were found discriminatory, with their primary focus on the native speaker status and nationality as a requirement. In the same way, Selvi (2010), in his analysis of online job postings, revealed evidence of discrimination against non-native teachers of English in giving preference to teachers from the Anglophone countries. His report demonstrated that nearly two-thirds of the TESOL ads had a native speaker or native-like proficiency as a prerequisite for a TEFL position.

Consistent results were found in Clark and Paran's (2007) study in the UK examining employers' requirements for a position of English as a Second/Foreign language (ESL/EFL) teacher. Their conclusions indicated that although academic qualifications and teaching experience were ranked as the two most important requirements, $72 \%$ of recruiters were steered by the native speaker criterion when making hiring decisions. Similar findings, documented in Saudi Arabia (Alenazi, 2014; Alshammari, 2021), South America (Mackenzie, 2021), and some Asian countries (Jeon \& Lee, 2006), confirmed either explicit or implicit preference of candidates from the anglophone 'Inner Circle' (Kachru, 1986) countries, including the USA, the UK, Canada, Australia, and New Zealand.

As noted elsewhere (Braine, 1999b, p. 22; Wang \& Lin, 2013), inequities in relation to NNESTs are also associated with the disparities between the salaries of native and non-native ESL teachers, an injustice that has a detrimental effect on their self-image. Others (e.g., Braine, 1999b; Lippi-Green, 1997), investigating the effect of speaking with a particular accent on one's (un)suitability for employment, found that the holders of the standard pronunciation, typically British or American, were readily employed, while non-native candidates often got disqualified because of their accented speech. As also evidenced by Timmis (2002) and Butler (2007), employers' choices are frequently justified by the premise that students prefer a native speaker as an ideal linguistic model. An analogous situation exists in the French educational context (see, e.g., Derivry-Plard, 2016; Derivry-Plard \& Griffin, 2017).

Another prejudice in ELT recruitment practices described by Ruecker (2011) concerns visa regulations established by certain countries as an additional gatekeeping measure to bar non-native teachers from the 'circle of the privileged. These preferential biases can be further underpinned by a sizable number of teachers' reflective accounts (Braine, 1999b) of battling their way to have their 'place under the sun'. My own experience of applying for various teaching jobs came with similar caveats; being a holder of an MA 
degree obtained in the UK and having a certified near-native language proficiency, I was still perceived as less competent than the native English-speaking applicants.

I could list many more instances of unfair practices in relation to NNESTs, but there is not enough space to include all of them here. One point is worth underlining, however. Given this context, the marginalisation of NNESTs in the employment domain speaks volumes about the prevailing wisdom of the ELT framework in general as having a propensity to perpetuate a legacy of the native speaker by preferential acceptance of NESTs as ideal teachers. Admittedly, a redefinition of native speakerism that would help end NNESTs categorisation and restore parity has been a subject of much attention among many researchers (Canagarajah, 1999a; Derivry-Plard, 2018, 2020; Medgyes, 1994; Pennycook, 1994; Rampton, 1990). Yet, paradoxically enough, after so many years of trying to eradicate the 'tyranny of native-speakerism' (Swan et al., 2015, p. 1), its ghost still haunts the linguistic grounds of the ELT universe. It is also quite ironic that almost a quarter of a century later, since the NNEST Caucus (Braine, 1999a) in concert with the TESOL organisation (TESOL, 1992, 2006) initiated its work to confront the discourses of 'othering' and establish a more equitable ELT field, the struggle of non-native educators for their legitimacy in the profession is still very much alive.

To gain a better understanding of the ideological nature of this struggle, one has to go beyond the surface acquaintance with the definition of the NEST/NNEST issue. In this sense, Bourdieu's conceptualisation of symbolic domination, to which I turn next, helps uncover the causes of inequality and the asymmetrical position non-native teachers hold in reference to their native counterparts.

\section{TESOL as a site of symbolic violence: a sociological perspective}

Essential to the purpose of the present discussion of inequalities between NESTs and NNESTs are Bourdieu's notions of field, capital, and habitus. Fields need to be understood as rule-governed multidimensional social spaces wherein differentiated positions individuals occupy are defined by the sum of resources or capital they hold (Thompson, 1991, p. 14). Apart from economic capital or one's material well-being, Bourdieu (1986) distinguishes cultural capital and social capital, which, unlike economic capital, are acquired over time. Cultural capital can be described as a stock of symbolic attributes, including knowledge, competencies, behaviours, credentials, and other assets of a certain value that people use to achieve a social advantage.

According to Bourdieu (1986), cultural capital comes in three forms: embodied, objectified, and institutionalised. In its embodied state, it refers to a set of 'long-lasting dispositions of the mind and body' (p. 243). These include physical and cognitive skills, linguistic practices, and manners cultivated through a process of socialisation and education. Incorporated into an individual, embodied cultural capital becomes what Bourdieu termed as habitus, described by him as internalised, durable 'dispositions that incline agents to act and react in certain ways' (Thompson, 1991, p. 12) in accordance with the intrinsic logic of the social world. Habitus, inculcated first through family or primary pedagogic work (Bourdieu \& Passeron, 1990, p. 72) and later through formal schooling, gives not only an awareness of 'one's place' but also 'a sense of the place of others' (Bourdieu, 1989, p. 19). 
Objectified cultural capital consists of material objects or 'cultural goods', like books, paintings, machines and other cultural products of a specific monetary value that can be transferred or exchanged on the market. This type of capital is not elaborated on in the paper. Institutionalised cultural capital manifests itself through academic achievements in the shape of qualifications, credentials, and certificates that grant its owners public recognition or, as Bourdieu (1986) puts it, 'constant, legally guaranteed value' (p. 248). Easily convertible into economic capital, it provides access to social capital, which has to do with social connections, networks, or membership into groups that the stakeholder can successfully monetise over time. At the same time, however, Bourdieu asserts () that all kinds of capital cannot be validated as legitimate unless they are transformed into symbolic capital, which only when socially recognised, exudes power through a form of distinction and prestige that establishes one's value within a social hierarchy.

Using Bourdieu's conceptual framework, I define TESOL as a field in which English language teachers occupy 'differentiated positions, defined... by the distribution of a particular kind of capital' (Bourdieu, 1998, p. 15). Central to its operation are the 'rules' (Bourdieu, 1991, p. 215) set by the colonial ideologies (see, for example, Canagarajah, 1999a; Pennycook, 1998) that have secured English its hegemonic position across the globe. The status of English as a dominant language, lingua franca (Crystal, 2012), was further enhanced through seemingly non-coercive forces of globalisation, which, promulgating it as a gateway to one's economic betterment, have made the proficiency in English a desirable symbolic capital tradable in the labour market. From this perspective, those in possession of required linguistic capital, part of embodied cultural capital, as Bourdieu and Passeron (1990, p. 74) contend, have better chances to succeed academically and professionally. It seems reasonable then to suppose that a non-native teacher of English generally possesses less linguistic capital and less appropriate habitus than a native English teacher; thus, their access to the benefits of the linguistic market is limited or denied. It is therefore unsurprising that within the language teaching field, the former occupy a niche that is asymmetrical in terms of power, in contrast to the latter, whose authority is universally recognised as legitimate.

The legitimisation of a native speaker is realised via the imposition of language ideologies mentioned earlier, which can be seen as the views of dominant groups that serve to impose a particular vision of the ELT world and (re)produce and maintain its unequal power dynamics. One such ideology, the idealisation of a native speaker, a concept proposed by Chomsky $(1965)$ and coined by Holliday $(2005,2006)$ as native speakerism, identifies a native speaker as a predominantly Western, middle class, mostly monolingual individual of white ethnicity, whose first language is English and who is characterised by an unmarked accent and linguistic proficiency inherited at birth (Braine, 1999b; Cook, 1999; Davies, 2003; Kubota, 1998). This essentialisation of a native speaker as ideal resulted in perpetuating the native-speaker fallacy (Phillipson, 1992), a takenfor-granted assumption that accords native speakers with higher status as teachers than non-native speakers.

Language ideologies have become 'naturalised' through what Bourdieu and Passeron (1990) name as symbolic violence, the 'power which manages to impose meanings... as legitimate by concealing the power relations' (p. 4). Symbolic violence is achieved through the process of misrecognition. For the authors, misrecognition occurs 
whenever practices of power and domination are perceived as 'legitimate in the eyes of the beholder'(p. xxii). Put differently, they are 'misrecognised' by us as non-arbitrary by appearing 'natural' and hence unquestionable. Thus, symbolic violence is successful when unnoticeably exerted, it comes to dominate people by their unawareness of being subjected to it and with their full complicity (Bourdieu \& Wacquant, 1992, p. 167). Viewed this way, it bears a resemblance to Gramsci's (1971) notion of hegemony, which he defines as 'the "spontaneous" consent' of the public 'to the general direction imposed on social life by the dominant fundamental group' (p. 12). I will return to his idea later, but we can see in this context, the symbolic imposition or the hegemony of the native speaker is misrecognised as a cultural arbitrary. A cultural arbitrary, which is 'embedded in the system of power relations between groups and classes' (Bourdieu \& Passeron, 1990, p. 57), occurs whenever one's beliefs, decisions, and values are forced upon others during the process of communication.

In the ELT industry, the exercise of symbolic violence is clearly traceable in the imposition of teaching materials, approaches, and standardised methods of assessment (IELTS, TOEFL) imported from the West. By way of illustration, 'English-only' orientation, eagerly employed by educational institutions worldwide, is accepted as legitimate through our (mis)perception of the language as a neutral medium of communication, an idea that has been cultivated in our minds since early years. On the other hand, such an innocent representation conveniently masks the fact that its global spread is most certainly infused with neocolonial vestiges of power and domination that depart from the 'Centre' (Pennycook, 1998; Phillipson, 1992). Equally misrecognised and arbitrary are Western-based BA and MA degrees and their add-ons CELTA and DELTA, which typically mirror intrinsically worthwhile Eurocentric ways of teaching and learning the language as normative (Anderson, 2015; Liu, 1998; McBeath, 2016). Importantly, however, constituting a considerable portion of one's cultural capital, its institutionalised form is used by employers as a legitimate basis for exclusion of teachers, especially non-native, from their participation in the TESOL profession 'on equal terms' (Canagarajah, 1999b, p. 87).

Going further, as Bourdieu and Passeron (1990, p. 54) assert, 'naturalisation' of this process occurs within the educational system, a formal structure that functions to inculcate the habitus of a dominant class and thereby legitimise and reproduce inequalities. Most of us, non-native educators, whether we admit it or not, internalise the difference between native and non-native habitus, or 'us' and 'them' during the initial years of our training. To shorten this gap, we willingly surrender ourselves to the native speakerist ideology that undergirds the majority of academic discourses. Now let me expand on that just a little further.

In my history as a student at the Teachers' Training University in Russia, NS idealisation was solidified in my consciousness via a 'hidden curriculum'. It involves knowledge instilled into the fabric of practices that carried with them non-dit rationales for accepting beliefs, values, behaviours, and 'norms' of a dominant culture-mainly British and American - as legitimate. Its symbolic enactment transpired across a range of disciplines from Theoretical Linguistics to Language Methodology in an essentially unconscious and non-imposing manner under the guise of 'learning the ropes'. To pass Practical Phonetics, for example, which required an accurate acquisition of the English 
sounds, entailed staying for hours in the language laboratory mastering my pronunciation first, by listening to the recordings of speakers talking in 'proper' English, also known as 'Queen's English' and afterwards, trying to mimic them. Eventually, especially after a period of time spent in the UK, I have become good at hiding my non-native habitus, albeit not always effectively; to this day, my unrolled ' $r$ ' still betrays my first language (L1) identity wherever I go. Years later, I was made aware of the symbolic power of an accent to carry either positive or negative connotations about its owners based on which they can be accepted into or left out of their chosen occupation. This point, noted previously in the paper, is also argued by Muggleston (2003), who maintains that an accent serves as a 'marker of group membership' (p. 43) and a symbol of one's 'internal worth and value' (p. 108). In these terms, acquiring the 'right' accent can be seen as a valuable linguistic capital that many, if not all, NNESTs like myself strive to accumulate.

As cultural and symbolic capital 'become the condition for an objective competition' (Bourdieu, 1991, p. 55) in a job market, more and more teachers are prompted to obtain their degrees in Western institutions. My decision to study in the UK was reminiscent of Canagarajah's (2012) observations, who noted how his own considerations had been influenced by the arguments in favour of studying in a Western country. Similarly, my aspiration was to furnish myself with Western knowledge, the desired capital that would add me an authoritative voice as a teacher. Nevertheless, being fully equipped with the 'right' capital, I was still a lesser teacher than a NEST in the eyes of the employers, which made me painfully realise that I am probably like the majority of teachers in TESOL who are non-native speakers of English (Canagarajah, 1999b, p. 91), who are counted just as an 'unnecessary by-product of the MA and PhD programs' (Braine, 1999b, p. xiii).

My recent inquiry into the TEFL world of work has left me with a familiar dismal picture. Deligitimisation of NNESTs in the spirit of the 'native-speakers-only-can-apply' approach remains stubbornly pervasive among various international institutions whose hiring policies continuously work to prioritise native speakerhood over one's educational background and professional expertise. This brings us back to the beginning of the conversation about the symbolic boundaries between NESTs and NNESTs effectuated by the ideology of native speakerism and maintained through binary markers such as 'native/non-native,' 'Centre/Periphery', 'legitimate/illegitimate,' 'correct/incorrect' which are 'coded into the DNA of ELT' (Kramsch, 2018, p.vi).

At this point, given the subjective nature of my involvement in the discussion, I should probably come to terms with the rationalisations of who is to blame for my marginal status. The reality, however, as we shall see in the next section, is much more complex and uncomfortable.

\section{Problematising the NEST-NNEST divide}

Continuous juxtaposition of NNESTs and NESTs has facilitated the rhetoric that keeps this dichotomy in constant circulation in various ELT contexts. Within this frame, the former are assumed a status of 'victims', and the latter are seen as 'perpetrators' (Rivers, 2018). To elaborate, the concept of native speakerism, which deems NSs as 'authentic owners' (Widdowson, 1994, p. 387) of the language, makes them proprietors and purveyors of Western knowledge by default and, as such, idealised language teachers. In contrast, NNESTs, lacking the authority over the language, encounter forms of 
discrimination, resulting in perceiving themselves as not up to par with their NS teaching colleagues. As a result, by classifying themselves as inferior, NNESTs often endorse 'feelings of guilt and shame' (Rivers, 2018, p. 194) among native-speaking educators for holding them accountable for existing inequity in the field. In essence, by consistently viewing themselves as a different group, the author contends (p. 191), NNESTs contribute to their own marginalisation.

On a different note, Copland et al. (2016) regretfully observe the tendency of the nonnative scholarship to 'other' NESTs by imagining them as 'monolingual', 'ill-equipped', 'ineffective', and 'unqualified. One way such 'othering' could be achieved is through the idealisation of NNESTs who have been framed most famously by Medgyes (1992, 1994) as more effective teachers by having qualities that native-speakers lack, for instance, sensitivity to students' cultures; in other words, by being what NESTs are not. Despite a range of derogatory terms in reference to NESTs, they can also be considered victims of marginalisation in recruitment and workspaces. Yazan and Rudolph (2018) usefully provide us with this evidence by presenting an impressive array of inquiries into the lives of expatriate NESTs that demonstrate the complexities inherent to their strive to earn legitimacy as English teachers, notwithstanding their 'non-standard' pronunciation, non-Western names and non-white appearance. Others (e.g., Houghton \& Rivers, 2013; Kubota \& Fujimoto, 2013; Lowe, 2020), too, acknowledge the ways in which issues surrounding race, nationality, and class populate a variety of educational habitats where NESTs live and work.

There is, of course, 'the other side of the coin', which leads me to believe that NNETs may be held partially responsible for promoting native speakerist thinking. A curious phenomenon that I described earlier is the desire of non-native speakers to some degree to be distinguished as native by acquiring native-speaker-like behaviours. As an example, Baratta (2016) explains that modifying one's accent as a 'deliberate strategy' can be adopted by individuals as 'selling out' at a job interview (p. 291). Such motivations may indicate their inclination toward adopting an identity associated with a more prestigious linguistic variety for 'symbolic rather than communicative purposes' (Davies, 2003, p. 76).

Finally, Canagarajah (1999b), in line with Phillipson (1992), has been extremely critical toward the role of Periphery academic institutions in reinforcing the native speaker status and sustaining NEST/NNEST taxonomy by being reliant on the Centre in terms of professional guidance. According to him, they are 'among the worst culprits to popularize and/or legitimize the native speaker fallacy' (p. 83). What he also finds questionable is the 'absurdity of an educational system that prepares one for a profession for which it disqualifies the person at the same time' (p. 77).

Problematising a NS construct, Davies (2003) makes a well-reasoned argument that the boundaries between the two camps are 'as much created by non-native speakers as by native speakers themselves' (p. 9). As native speakerism raises expectations, both kinds of teachers as transmitters of 'norms' are compelled to disseminate the knowledge that emanates from the West by the power of pedagogic authority (Bourdieu \& Passeron, 1990) that sanctions their actions to deliver a message of a dominant group through enacting language ideologies. After all, all ESL/EFL teachers, as Kaplan (2000) suggests, are 'offsprings and heirs of foreign language departments and their policies' (p.viii); 
therefore, they 'have an obligation' (Bourdieu \& Passeron, 1990, p. 113) towards their institutions to inculcate knowledge in the manner previously acquired by themselves. Consequently, symbolic imposition of a particular variety of English as a standard, for example, is 'decided as much by those who regard themselves as oppressed as by their oppressors' (Davies, 2003, p. 150). From this stance, native-speaking and second language (L2) teaching professionals are co-creators of inequalities, and in Bourdieu and Passeron's (1990) language, players of the reproduction 'game' (p. 132).

It has also been observed by some scholars (Davies, 2003; Hackert, 2012) that NS and NNS are fluid categories. More specifically, Davies (2003) claims that non-native speakers can 'choose native speaker membership' (p. 165) provided they gain language proficiency whether they live in the L2 environment or not. At the same time, as Copland et al. (2020) maintain, native speakers, in contrast to their lingering portrayals in the literature as monolingual, are often multilingual and multicultural. We tend to forget that similar to non-natives, NS identities are, too, complex and dynamic as their negotiation takes place 'in-between spaces' (Bhabha, 1994) at the juncture of global and local discourses. Therefore, we should be heedful of treating these two groups as culturally distinct.

What is also true is that under the World Englishes paradigm (Kachru, 1992), hybridised English varieties have been successfully used to negotiate the meaning in interactions across the local and global borders. This perspective should alter our understanding of the linguistic nativity axiom, more notably of the ownership of English, whom it belongs to, and what it means to be a native and non-native speaker.

Ultimately then, it is quite logical that an idealisation of a native speaker is 'a useful myth' (Davies, 2003, p. 214) that needs to be dispelled. If we take this argument seriously, the dispute over who makes a better teacher has to be terminated on the grounds that native and non-native teachers are not entirely dissimilar with respect to who they are as plurilingual individuals and what they do as classroom educators. One would also think that the TESOL world that champions equality and celebrates diversity should be concentrating on ending the NEST-NNEST typology by giving each category of teachers an equal voice instead of just privileging the one that is already powerful. Instead, such binarism is 'actively embraced rather than rejected' (Rivers, 2018, p. 189). Nevertheless, an equitable and prejudice-free language teaching field is very far from reality. Its destiny, as the preceding discussion should have made clear, inevitably lies in the hands of the hegemonic Centre, which has its grip firmly on the current methodological orthodoxy and how it develops.

\section{Towards a more equitable ELT field}

Thus far, it has been argued that the field of TESOL is a terrain riddled with struggle and contestation for 'the definition of the legitimate principles of division of the field' (Bourdieu, 1991, p. 242). Within this narrative, as illustrated above, the hegemony of native speakerism as a leading discourse has oriented the field in such a way that NESTs are positioned as the dominant group while NNESTs are ascribed the role of the dominated.

Referring back to the Gramscian idea of hegemonic power I considered a little earlier, these two oppositional classes can also be denoted as 'hegemonic' and 'subaltern' 
respectively. Gramsci (1971) captures their relations very well when he says that the 'subaltern force' that has to be constantly 'manipulated' is prevented from ever rising above the dominant (p. 160). Drawing on this concept, Kumaravadivelu (2016), one of the avid postcolonial/poststructural scholars and a non-native speaker himself, urges the subaltern community to resist 'the marginality of the majority'. To him, it would entail going beyond merely 'articulat[ing] their concerns' (p. 72) that barely leave the NNEST coteries. Such thinking implies a critical (re)evaluation of an imposed vision of the ELT world and activation of their 'agentive capacity' (p. 78) that will allow them to act collectively towards restructuring the relations of subordination and domination. In this respect, the role of human agency, that is, the ability to confront the pernicious nature of inequality, as Giroux (1983) posits, has been somewhat excluded from Bourdieu and Passeron's relatively static interpretation of the relationships between the dominant and dominated classes.

One way to exercise agency, Kumaravadivelu sees in a decolonial option, which in Mignolo's (2010, p. 313) terms means 'de-naturaliz[ing] concepts' of the colonial Centre. Under its logic, subaltern intellectuals would have to recognise their power to bring change by showing their independence from 'Center-based knowledge systems'(Kumaravadivelu, 2016, p. 82) and 'localising' their teaching approaches and materials. Above all and most importantly, NNESTs would need to stop proving that they can 'teach well' and being apologetic for who they are.

Agreeing with the above, I do not wish to imply, however, that Western knowledge has been irrelevant in my or any non-native teacher's academic and professional journey. By doing so, I would undermine the value of native speakers in language acquisition that cannot be denied (Davies, 2003, p. 165). More than that, as my 'comrades-in-arms', they, very much like me, have 'no say... no right to intervene or pass judgment' on matters pertaining to English development and how it unfolds globally (Widdowson, 1994, p. 385). I am, however, saying that they need to be more cognizant of their role in the issue of inequality and perhaps assume greater responsibility for the power they wield in the classroom, whose values they propagate among their students, and why.

\section{Conclusion}

Following Kumaravadivelu's lead to think 'otherwise', I have engaged myself in a critical examination that set out to explore the issue of inequality between native and non-native English teachers. This is where Bourdieusian theorisation of capital and symbolic power has been particularly useful as it allows us to better understand the true function of the seemingly neutral and commonly accepted processes in the reproduction of inequalities.

In addressing the problem, the paper has sought to challenge the ideological discourses of native speakerism that set up, 'normalise', and patrol the symbolic boundaries of privilege and marginalisation, classifying teachers into separate groups in proportion to their symbolic capital. From this stance, TESOL, like any other field, is a site of 'symbolic struggles' (Bourdieu, 1989, p. 20) where native and non-native language professionals vie for their legitimate recognition. Through Bourdieu's lens, it becomes quite clear that the possession of a greater hereditary capital afforded to native speakers of English as a birthright is used as a vehicle to justify the discriminatory treatment of non-native educators in recruitment spaces as having ineligible 
linguistic habitus. However, later, I had a reason to interrogate this claim by adding that NESTs themselves can fall into the category of 'the stigmatised' if their cultural background does not 'fit' into the idealised images of an English teacher.

What I hope the reader finds quite convincing is that all of us, language teaching specialists, are to some extent answerable for sustaining the facture among ourselves that has been hard to repair so far. If anything, the realisation of the disparities that have been driving us away from each other should be in itself a liberating thought that would free us from the illusory world that the hegemonic Centre has enforced on us. Let this awareness nudge us towards a solidary union of language teaching intellectuals bound by common counter-hegemonic practices that look beyond the native-speaker paradigm. Against this horizon, English language teaching is not only an 'arena of struggle', as Bourdieu (1991) asserts, but also resistance. Still, Gramsci (1971) cautions us against the possibility for resistance to be offered by the dominant group or forces 'allied to those which are dominant' (p. 279). In this regard, we are still grappling with the forces of neoliberalism that find ways to utilise what Canagarajah (2017) describes as 'translingual practices', such as multilingualism, in their mercantile interest of profit-making.

Therefore, as multilingual human beings, together, we must stay alert to the emerging ideological canons and hierarchies that such tendencies aim to insinuate. It is only in the spirit of like-mindedness that we could maximise our capacity to withstand the already existing and new boundaries that demarcate our identities and discard our roles and values as language teachers.

\begin{abstract}
Abbreviations
CELTA: Certificate in Teaching English to Speakers of Other Languages; DELTA: Diploma in Teaching English to Speakers of Other Languages; ELT: English language teaching; IELTS: International English Language Testing System; L1: First language; L2: Second language; MA: Master of Arts (degree); NESTs: Native English-speaking teachers; NNESTS: Non-native English-speaking teachers; NS: Native speaker; NNS: Non-native speaker; PhD: Doctor of Philosophy; TESOL: Teaching English to speakers of other languages; TOEFL: Test of English as a Foreign Language.
\end{abstract}

Acknowledgements

Not applicable.

Authors' contributions

NW wrote the main manuscript text. The author read and approved the final manuscript.

Funding

Not applicable.

Availability of data and materials

Not applicable.

\title{
Declarations
}

Ethics approval and consent to participate

Not applicable.

Consent for publication

Not applicable.

Competing interests

The authors declare that they have no competing interests.

Author details

${ }^{1}$ University of Glasgow, Glasgow, UK. ${ }^{2}$ American University of the Middle East, Kuwait, Kuwait.

Received: 8 November 2021 Accepted: 24 January 2022

Published online: 27 January 2022 


\section{References}

Alenazi, O. (2014). The employment of native and non-native speaker EFL teachers in Saudi higher education institutions: Programme administrators' perspective. [Doctoral dissertation]. Newcastle University, United Kingdom. Retrieved June 15, 2021, from https://core.ac.uk/download/pdf/153778904.pdf

Alshammari, A. (2021). Job advertisements for English teachers in the Saudi Arabian context: Discourses of discrimination and inequity. TESOL Journal. https://doi.org/10.1002/tesj.542

Anderson, J. (2015). Initial teacher training courses and non-native speaker teachers. ELT Journal, 7(3), 261-274. https://doi. org/10.1093/elt/ccv072

Baratta, A. (2016). Keeping it real or selling out the effects of accent modification on personal identity. Pragmatics and Society, 7(2), 291-319. https://doi.org/10.1075/ps.7.2.06bar

Bhabha, H. K. (1994). The location of culture. Routledge.

Bourdieu, P. (1986). The forms of capital. In J. G. Richardson (Ed.), Handbook of theory and research for sociology of education (pp. 241-258). Greenwood.

Bourdieu, P. (1989). Social space and symbolic power. Sociological Theory, 7, 14-25. https://doi.org/10.2307/202060

Bourdieu, P. (1991). Language and symbolic power. Harvard University Press.

Bourdieu, P. (1998). Practical reason: On the theory of action. Stanford University Press.

Bourdieu, P., \& Passeron, J. C. (1990). Reproduction in education, society and culture. Sage.

Bourdieu, P., \& Wacquant, L. (1992). An Invitation to reflexive sociology. University of Chicago Press.

Braine, G. (1999a). NNS and invisible barriers in ELT. TESOL Matters, 2(2), 14.

Braine, G. (Ed.). (1999b). Non-native educators in English language teaching. Erlbaum.

Braine, G. (2010). Nonnative speaker English teachers: Research, pedagogy, and professional growth. Routledge.

Butler, Y. G. (2007). How are nonnative-English-speaking teachers perceived by young learners? TESOL Quarterly, 41, 731-755. https://doi.org/10.1002/j.1545-7249.2007.tb00101.x

Canagarajah, A. S. (1999a). Resisting linguistic imperialism in English teaching. Oxford University Press.

Canagarajah, A. S. (1999b). Interrogating the Native Speaker Fallacy": Non-linguistic roots, non-pedagogical results. In G. Braine (Ed.), Non-native educators in English language teaching (pp. 77-92). Lawrence Erlbaum.

Canagarajah, A. S. (2012). Teacher development in a global profession: An autoethnography. TESOL Quarterly, 46(2), 258-279. https://doi.org/10.1002/tesq.18

Canagarajah, S. (2017). Translingual practices and neoliberal policies: Attitudes and strategies of African skilled migrants in Anglophone workplaces. Springer.

Chomsky, N. (1965). Aspects of the theory of syntax. MIT Press.

Clark, E., \& Paran, A. (2007). The employability of non-native-speaker teachers of EFL: A UK survey. System, 35, 407-430. https:// doi.org/10.1016/.jsystem.2007.05.002

Cook, V. (1999). Going beyond the native speaker in language teaching. TESOL Quarterly, 33(2), 185-209. https://doi.org/10. 2307/3587717

Copland, F., Garton, S., \& Mann, S. (Eds.). (2016). LETs and NESTs: Voices, views and vignettes. London: British Council.

Copland, F., Mann, S., \& Garton, S. (2020). Native-English-Speaking teachers: Disconnections between theory, research, and practice. TESOL Quarterly, 54(2), 348-374. https://doi.org/10.1002/tesq.548

Crystal, D. (2012). English as a global language (2nd ed.). Cambridge: Cambridge University Press.

Davies, A. (1991). The native speaker in applied linguistics. Edinburgh University Press.

Davies, A. (2003). The native speaker: Myth and reality (2nd ed.). Multilingual Matters.

Derivry-Plard, M. (2016). Symbolic power and the native/non-native dichotomy: Towards a new professional legitimacy. Applied Linguistics Review, 7(4), 431-448.

Derivry-Plard, M. (2018). A multilingual paradigm in language education: What it means for language teachers. In S. A. Houghton \& K. Hashimoto (Eds.), Towards post-native-speakerism: Dynamics and shifts (pp. 131-148). Springer.

Derivry-Plard, M. (2020). A multilingual paradigm: Bridging theory and practice. In S. A. Houghton \& J. Bouchard (Eds.), Nativespeakerism: Its resilience and undoing (pp. 157-172). Springer.

Derivry-Plard, M., \& Griffin, C. (2017). Beyond symbolic violence in ELT in France. In J. Dios-Martinez-Aguda (Ed.), Native and non-native teachers in English language classrooms: Professional challenges and teacher education (pp. 33-52). De Gruyter Mouton.

Epstein, C. F. (1992). Tinker-bells and pinups: the construction and reconstruction of gender boundaries at work. In M. Lamont \& M. Fournier (Eds.), Cultivating differences: Symbolic boundaries and the making of inequality (pp. 232-256). University of Chicago Press.

Giroux, H. (1983). Theories of reproduction and resistance in the new sociology of education: A critical analysis. Harvard Educational Review, 53(3), 257-293. https://doi.org/10.17763/haer.53.3.a67×4u33g7682734

Gramsci, A. (1971). Selections from the prison notebooks (Q. Hoare \& G. N. Smith, Trans. and Ed.). International Publishers.

Hackert, S. (2012). The emergence of the English native speaker. De Gruyter Mouton.

Holliday, A. (2005). The struggle to teach English as an international language. Oxford University Press.

Holliday, A. (2006). Native-speakerism. ELT Journal, 60(4), 385-387. https://doi.org/10.1093/elt/ccl030

Houghton, S., \& Rivers, D. J. (2013). Native-speakerism in Japan: Intergroup dynamics in foreign language education. Berlin: Multilingual Matters.

Jeon, M., \& Lee, J. (2006). Hiring native-speaking English teachers in East Asian countries. English Today, 22(4), 53-58. https:// doi.org/10.1017/S0266078406004093

Kachru, B. B. (1986). The alchemy of English: The spread, functions and models of non-native Englishes. Pergamon.

Kachru, B. B. (1992). Teaching world Englishes. The other tongue. University of Illinois Press.

Kaplan,. (2000). Foreword. In J. K. Hall \&W. G. Eggington (Eds.), The sociopolitics of English language teaching. Multilingual Matters.

Kramsch, C. (2018). Foreword. In B. Yazan \& N. Rudolph (Eds.), Criticality, teacher identity, and (in)equity in English language teaching. Springer.

Kubota, R. (1998). Ideologies of English in Japan. World Englishes, 17, 295-306. https://doi.org/10.1111/1467-971x.00105 
Kubota, R., \& Fujimoto, D. (2013). Racialized native speakers: Voices of Japanese American English language professionals. In S. Houghton \& D. J. Rivers (Eds.), Native-speakerism in Japan: Intergroup dynamics in foreign language education (pp. 196-206). Multilingual Matters.

Kumaravadivelu, B. (2016). The decolonial option in English teaching: Can the subaltern act? TESOL Quarterly, 50(1), 66-85. https://doi.org/10.1002/tesq.202

Lippi-Green, R. (1997). English with an accent: Language, ideology, and discrimination in the United States. Routledge.

Liu, D. (1998). Ethnocentrism in TESOL: Teacher education and the neglected needs of international TESOL students. ELT Journal, 52(1), 3-10. https://doi.org/10.1093/elt/52.1.3

Liu, J. (1999). Nonnative English speaking professionals in TESOL. TESOL Quarterly, 33, 85-102. https://doi.org/10.2307/35881 92

Llurda, E. (Ed.). (2006). Nonnative language teachers: Perceptions, challenges and contributions to the profession. Springer.

Lowe, R. J. (2020). Uncovering ideology in English language teaching: Identifying the "native speaker" frame. Springer.

Mackenzie, L. (2021). Discriminatory job advertisements for English language teachers in Colombia: An analysis of recruitment biases. TESOL Journal. https://doi.org/10.1002/tesj.535

Mahboob, A. (2005). Beyond the native speaker in TESOL. In Z. Syed (Ed.), Culture, context, and communication in English language teaching (pp. 60-93). Military Language Institute.

Mahboob, A. (Ed.). (2010). The NNEST lens: Nonnative English speakers in TESOL. Cambridge Scholars.

Mahboob, A., \& Golden, R. (2013). Looking for native speakers of English: Discrimination in English language teaching job advertisements. Voices in Asia Journal, 1(1), 72-81.

McBeath, N. (2016). Initial teacher training courses and non-native speaking teachers: A response to Jason Anderson. ELT Journal, 71(2), 247-249. https://doi.org/10.1093/elt/ccw090

Medgyes, P. (1992). Native or nonnative: Who's worth more? ELT Journal, 46(4), 340-349. https://doi.org/10.1093/elt/46.4.340

Medgyes, P. (1994). The non-native teacher. Hueber.

Medgyes, P. (2001). When the teacher is a nonnative speaker. In M. Celce-Murcia (Ed.), Teaching English as a second or foreign language (pp. 429-442). Heinle \& Heinle.

Mignolo, W. (2010). Delinking: The rhetoric of modernity, the logic of coloniality and the grammar of de-coloniality. In W. Mignolo \& A. Escobar (Eds.), Globalization and the decolonial option (pp. 303-368). Routledge.

Moussu, L. (2006). Native and non-native English-speaking English as a second language teachers: Student attitudes, teacher selfperceptions, and intensive English program administrator beliefs and practices. [Unpublished doctoral dissertation]. Purdue University, Lafayette, IN. Retrieved June 30 2021, from https://eric.ed.gov/?id=ED492599

Moussu, L., \& Llurda, E. (2008). Non-native English speaking English language teachers: History and research. Language Teaching, 41(3), 315-348. https://doi.org/10.1017/s0261444808005028

Mugglestone, L. (2003). Talking proper: The rise of accent as social symbol. University Press.

Paikeday, T. M. (1985). The native speaker is dead! Paikeday Publishing.

Pennycook, A. (1994). The cultural politics of English as an international language. Longman.

Pennycook, A. (1998). English and the discourses of colonialism. Routledge.

Phillipson, R. (1992). Linquistic imperialism. Oxford University Press.

Rampton, M. B. H. (1990). Displacing the "native speaker": Expertise, affiliation and inheritance. ELT Journal, 44(2), 97-101. https://doi.org/10.1093/elt/44.2.97

Rivers, D. J. (2018). Speakerhood as segregation: The construction and consequence of divisive discourse in TESOL. In B. Yazan \& N. Rudolph (Eds.), Criticality, teacher identity, and (in) equity in English language teaching (pp. 179-197). Springer.

Ruecker, T. (2011). Challenging the native and nonnative English speaker hierarchy in ELT: New directions from race theory. Critical Inquiry in Language Studies, 8(4), 400-422. https://doi.org/10.1080/15427587.2011.615709

Ruecker, T., \& Ives, L. (2015). White native English speaker needed: The rhetorical construction of privilege in online teacher recruitment spaces. TESOL Quarterly, 49(4), 733-756. https://doi.org/10.1002/tesq.195

Selvi, A. (2010). All teachers are equal, but some teachers are more equal than others: Trend analysis of job advertisements in English language teaching. WATESOL NNEST Caucus Annual Review, 1, 156-181.

Selvi, A. (2014). Myths and misconceptions about nonnative English speakers in TESOL (NNEST) movement. TESOL Journal, 5 , 573-611. https://doi.org/10.1002/tesj.158

Swan, A., Aboshiha, P., \& Holliday, A. (Eds.). (2015). (En)Countering Native-speakerism. Palgrave Macmillan.

TESOL. (1992). Statement on nonnative speakers of English and hiring practices. TESOL Matters, 2(4), 23.

TESOL. (2006). Position statement against discrimination of nonnative speakers of English in the field of TESOL. Retrieved June 24, 2021, from http://www.tesol.org/docs/pdf/5889.pdf?sfvrsn=2

Thompson, J. B. (1991). Editor's introduction. In P. Bourdieu (Ed.), Language and symbolic power. Polity Press.

Timmis, I. (2002). Native-speaker norms and international English: A classroom view. ELT Journal, 56, 240-249. https://doi.org/ 10.1093/elt/56.3.240

Wang, L., \& Lin, T. (2013). The representation of professionalism in native English-speaking teachers recruitment policies: A comparative study of Hong Kong, Japan, Korea and Taiwan. English Teaching: Practice and Critique, 12(3), 5-22.

Widdowson, H. G. (1994). The ownership of English. TESOL Quarterly, 28, 377-389. https://doi.org/10.2307/3587438

Yazan, B., \& Rudolph, N. (Eds.). (2018). Criticality, teacher identity, and (in)equity in English language teaching: Issues and implications. Springer.

\section{Publisher's Note}

Springer Nature remains neutral with regard to jurisdictional claims in published maps and institutional affiliations. 